\title{
Perubahan Histologi dan Fisiologi Latisifer pada Tanaman Karet (Hevea brasiliensis Muell Arg.) yang diberi Asam Jasmonat dan Asam Naftalen Asetat Eksogen
}

\section{Histological and Physiological Changes of Rubber Tree (Hevea brasiliensis Muell Arg.) Laticifere under Exogenous Jasmonic Acid and Naphtalene Acetic Acid Treatments}

\author{
Radite Tistama $^{1 *}$, Vahnoni Lubis ${ }^{2}$, Isnaini Nurwahyuni ${ }^{2}$ \\ ${ }^{1}$ Balai Penelitian Sungei Putih, Sungei Putih, Pusat Penelitian Karet Galang \\ Deliserdang Sumatera Utara \\ ${ }^{2}$ Program Studi Biologi, FMIPA Universitas Sumatra Utara, \\ Jl. Bioteknologi No.1 Kampus USU, Padang Bulan, Medan, Sumatera Utara \\ *Email: raditetistama@gmail.com
}

Diterima 7 Februari 2017/Disetujui 25 Februari 2017

\begin{abstract}
ABSTRAK
Produktivitas tanaman karet tergantung pada faktor dominan seperti jumlah latisifer dan aktivitas metabolism lateks. Perkembangan histologi dan fisiologi latisifer tanaman karet dipengaruhi oleh jenis klon dan interaksi antara zat pengatur tumbuh eksogen dengan klon. Perubahan histologi dan fisiologi latisifer Hevea brasiliensis diteliti dengan aplikasi asam jasmonat, asam naftalen asetat dan kombinasi keduanya pada permukaan tunas lateral muda. Hasil penelitian ini menunjukkan bahwa zat pengatur tumbuh menginduksi jumlah pembuluh kateks tetapi mengurangi perkembangan tebal kulit dan ukuran sel latisifer. Kombinasi JA dengan NAA paling efektif menginduksi jumlah pembuluh lateks pada klon metabolisme tinggi PB 260. Zat pengatur tumbuh memacu perubahan aktivitas fisiologi pada klon metabolisme rendah IRR 42. Analisis histologi kulit dan fisiologi lateks pada tunas muda tanaman karet dapat digunakan sebagai pendeteksi potensi produktivitas dan sifat metabolisme tanaman karet.
\end{abstract}

Kata kunci: Latisifer Hevea, asam jasmonat, asam naftalen asetat, metabolisme lateks

\section{ABSTRACT}

The rubber plant productivity is depend on the dominant factors such as laticifere number and latex metabolism activity. The histological and physiological development of rubber plant laticifere are affected the type of clones and interaction between exogenous plant growth regulator with clones. The changes of histological and physiological laticiferes of Hevea brasiliensis was investigated by application JA, NAA and their combination to the surface of the young lateral buds. The result showed, plant growth regulators induced the number of laticifere, but decreased of the laticifere cell size and bark thickness. The combination of JA with NAA was the most effective to induced laticifere number in high metabolism clone PB 260. The plant growth regulators led to change physiological activity in low metabolism clones IRR 42. The histological and physiological analysis of latisifer could be used to early detection of productivity and characters of rubber tree metabolism.

\section{Keywords: Hevea laticifere, jasmonic Acid, naphtalene acetic acid, latex metabolism}

\section{PENDAHULUAN}

Latisifer merupakan sel-sel khusus untuk mensintesis koloid yang disebut dengan lateks. Latisifer dijumpai sedikitnya pada 20 kelompok tanaman Angiospermae. Fungsi jaringan ini adalah sebagai alat pertahanan dengan menghasilkan lateks. Lateks mengandung berbagai jenis proteinprotein pertahanan terhadap penyakit (Breton et al. 1997; Daruliza et al. 2011).. Latisifer tanaman karet secara dinamis dibentuk oleh kambium dengan jumlah cincin latisifer lateks yang bervariasi tergantung klon (Woelan \& Sayurandi 2009). Latisifer yang terdiferensiasi lebih awal akan 
didesak ke arah luar oleh sel-sel latisifer yang baru dan pada umur tertentu latisifer akan mengalami lignisasi dan rusak (Sando et al. 2009).

Perakitan klon-klon karet unggul dilakukan dengan menggabungkan beberapa karakter genetik yang menentukan produksi karet yaitu ketebalan kulit, jumlah latisifer dan diameter latisifer serta aktivitas metabolisme karet (Woelan \& Sayurandi 2009). Selain faktor genetik, produktivitas tanaman karet juga dipengaruhi oleh faktor-faktor lingkungan (Daslin et al. 2009). Beberapa penelitian mengupayakan meningkatkan jumlah latisifer pada tanaman karet pada berbagai tingkat umur tanaman karet. Hoa \& Wu, (2000) melaporkan perlakuan asam jasmonat (JA) pada kulit tunas lateral muda meningkatkan 2-4 unit lingkar latisifer. Sementara itu Asam naftalen asetat (NAA) diketahui menginduksi penebalan kulit pada tanaman karet muda (Koryati, 2004). Rahayu et al. (2016) juga melaporkan bahwa perlakuan NAA meningkatkan diferensiasi sel latisifer tetapi tidak mempercepat pemulihan kulit.

Kombinasi JA dengan NAA diharapkan dapat meningkatkan tebal kulit dan jumlah latisifer tanaman karet. Pengaruh kombinasi JA dengan NAA terhadap perkembangan latisifer dan perubahan fisiologi lateks antar klon karet yang sifat metabolismenya yang berbeda belum diketahui. Penelitian ini betujuan untuk menguji peran JA dan NAA dalam menginduksi tebal kulit dan diferensiasi latisifer, serta perubahan fisiologi pada klon karet PB 260 (metabolisme tinggi) dan IRR 42 (metabolisme rendah).

\section{METODE PENELITIAN}

Bahan yang digunakan adalah tunas lateral tanaman Hevea brasiliensis Muell Arg umur 50 hari, klon jenis IRR 42 dan PB 260. Bahan kimia yang digunakan antara lain JA, NAA, whatman, parafilm, anthrone, TCA 2,5\%, $\mathrm{KH}_{2} \mathrm{PO}_{4}, \mathrm{H}_{2} \mathrm{SO}_{4}$, heptamolibdat, $\mathrm{NaCl} 0,9 \%, \mathrm{HNO}_{3}$, formalin, asam asetat, akuades, alkohol 70\%, alkohol absolut, sudan 3, aseton dan gliserin.

\section{Perlakuan JA dan NAA pada Tunas Lateral}

Entres umur 4 tahun masing-masing klon IRR 42 dan PB 260 dipangkas cabangnya pada jarak $10 \mathrm{~cm}$ dari pangkal cabang. Perkembangan tunas dikontrol setiap minggu dari muncul tunas lateral hingga tunas berumur 50 hari. Percobaan menggunakan Rancangan Petak Tersarang dengan tiga ulangan. Perlakuan terhadap tunas lateral menggunakan metode Hao dan Wu (2000) yang telah dimodifikasi. Tunas lateral berumur 50 hari dari setiap klon dibalut dengan whatman sepanjang $3 \mathrm{~cm}$ yang telah ditetesi $0,5 \mathrm{ml}$ larutan JA 1000 ppm, larutan NAA 1000 ppm dan kombinasi larutan JA dengan NAA 1000 ppm.

\section{Analisis Histologi}

Pembuatan preparat jaringan mengikuti metode Gomez et al (1972) yang telah dimodifikasi dan pewarnaan menggunakan Sudan III selama 30 menit. Sampel kulit batang diiris secara melintang menggunakan silet dan diamati di bawah mikroskop. Kulit dari masing-masing perlakuan diiris secara melintang dengan cara irisan tangan (free hand section). Tebal kulit dan jumlah latisifer dihitung di bawah mikroskop cahaya pada perbesaran 4 X 10. Jumlah latisifer dihitung pada penampang preparat sepanjang $500 \mu \mathrm{m}^{2}$ yang dilakukan pada 3 titik. Latisifer yang terhitung dicatat dan dihitung rata-ratanya. Diameter latisifer dihitung pada penampang preparat sepanjang 500 $\mu \mathrm{m}^{2}$ yang dilakukan pada 3 titik.

\section{Analisis Fisiologi}

Latek diambil dengan cara melukai kulit sepanjang $1 / 2$ lingkaran batang. Lateks disimpan di dikumpulkan di dalam botol plastik kemudian disimpan di dalam kotak es. Lateks sebanyak $1 \mathrm{ml}$ dimasukan ke dalam $9 \mathrm{ml}$ larutan 2,5\% trichloric acid (TCA). Koagulan lateks diekstrak menggunakan batang gelas untuk mengeluarkan serumnya. Serum disimpan pada suhu $4^{\circ} \mathrm{C}$ hingga digunakan.

\section{a. Analisis Kandungan Sukrosa}

Analisis kandungan sukrosa lateks dilakukan dengan mereaksikan $150 \mu \mathrm{L}$ sampel serum lateks dengan $350 \mu \mathrm{L} 2,5 \%$ TCA dan $3 \mathrm{ml}$ pereaksi anthrone kemudian divorteks. Sampel dimasukkan ke dalam waterbath pada suhu $95^{\circ} \mathrm{C}$ selama 15 menit, dan direndam ke dalam air biasa hingga 
dingin. Konsentrasi sukrosa dalam sampel diukur dengan spektrofotometer pada panjang gelombang $627 \mathrm{~nm}$ (Dische 1962).

\section{b. Analisis Kandungan Fosfat Anorganik}

Analisis kandungan fosfat anorganik dilakukan dengan menggunakan metode Taussky \& Shorr (1953). Sebanyak 0,3 ml sampel lateks dimasukkan ke dalam tabung reaksi dan ditambahkan TCA 2,5\% hingga volume $1,5 \mathrm{ml}$. Sampel ditambahkan $1 \mathrm{ml}$ pereaksi campur $\left(\mathrm{Fe}_{2} \mathrm{SO}_{4}\right.$ + akuades + larutan molibdat) kemudian divorteks. Sampel didiamkan selama 10 menit pada suhu kamar. Konsentrasi sampel diukur pada panjang gelombang $750 \mathrm{~nm}$.

\section{c. Analisis Produksi Karet}

Analisis produksi karet dilakukan dengan menggunakan metode Rachmawan \& Sumarmadji (2007). Tunas lateral tanaman disayat sepanjang $1 / 2$ keliling lilit batang pada bagian yang diberi perlakuan. Tetesan lateks yang keluar ditampung menggunakan kertas saring yang telah ditimbang beratnya hingga lateks berhenti mengalir. Lateks yang tertampung di atas kertas saring ditimbang untuk mendapati berat basah lateks. Lateks yang tertampung pada kertas saring dikeringkan di dalam oven selama 1 jam pada suhu $100-105^{\circ} \mathrm{C}$, kemudian ditimbang.

Data yang diperoleh dianalisis menggunakan Rancangan Petak Tersarang. Perlakuan yang menunjukkan perbedaan nyata diuji lanjut dengan uji jarak Duncan Multiple Range Test (DMRT) pada taraf $5 \%$.

\section{HASIL DAN PEMBAHASAN}

\section{Analisis Histologi}

\section{a. Tebal Kulit $(\mu \mathrm{m})$}

Kulit tunas lateral klon IRR 42 lebih tebal dibandingkan dengan klon PB 260. Ketebalan kulit tanaman karet bersifat genetis, hal tersebut ditunjukan dengan ketebalan klon IRR 42 yang lebih tebal dibandingkan PB 260 pada saat tanaman dewasa. Pertumbuhan tebal kulit akan mengikuti pertumbuhan lilit batang (Woelan dan Sayurandi, 2009). Perlakuan asam jasmonat, NAA dan kombinasinya tidak berpengaruh nyata terhadap peningkatan tebal kulit pada cabang muda IRR 42 dan PB 260. Tebal kulit klon IRR 42 cenderung mengalami penurunan dengan pemberian zat pengatur tumbuh bila dibandingkan dengan kontrol. Seperti dilaporkan oleh Rahayu et al. (2016) bahwa NAA tidak perpengaruh nyata terhadap peningkatan tebal kulit tanaman dewasa. Sebaliknya, penggunaan auksin alami IAA pada konsentrasi $50 \mathrm{ppm}$ tanaman muda menginduksi pertambahan tebal kulit yang nyata pada klon PB 260 tanaman Hevea brasiliensis (Koryati, 2004). Sementara itu asam jasmonat justru memberikan efek yang sebaliknya yaitu menghambat pertumbuhan tebal kulit. JA diketahui lebih berperan dalam diferensiasi latisifer di jaringan kulit tanaman karet (Wu et al. 2016).

Tabel 1. Pengaruh pemberian JA, NAA dan kombinasinya terhadap tebal kulit $(\mu \mathrm{m})$ tanaman pada klon karet PB 260 dan IRR 42.

\begin{tabular}{cccccc}
\hline Perlakuan & Kontrol & JA & NAA & JA+NAA & Rataan \\
\hline PB 260 & 880,54 & 860,64 & 917,26 & 892,44 & 887,72 \\
IRR 42 & $1601,23^{\mathrm{a}}$ & $1199,63^{\mathrm{c}}$ & $1450,39^{\mathrm{b}}$ & $1440,94^{\mathrm{b}}$ & 1423,05 \\
\hline
\end{tabular}

Keterangan: Angka-angka yang tidak diikuti huruf pada kelompok perlakuan yang sama menunjukkan tidak berbeda nyata menurut Uji Duncan's Multiple Range Test pada taraf $\alpha 5 \%$

Karakteristik tebal kulit karet yang memiliki korelasi positif terhadap potensi produksi lateks (Daslin et al., 2010). Kulit yang tebal memberikan ruang untuk meningkatnya jumlah latisifer. Namun demikian kulit yang tebal tidak selalu diikuti dengan jumlah latisifer. Dalam proses seleksi kandidat klon-klon unggul, ketebalan kulit dijadikan salah satu penciri klon unggul (Woelan 
dan Sayurandi, 2009). Tanaman dengan kulit yang terlalu tipis tidak diharapkan karena berpotensi besar untuk terjadi pelukaan kambium pada saat penyadapan (Kurnia, 2011).

\section{b. Jumlah Latisifer ( $\left.\operatorname{sel} / 500 \mu \mathrm{m}^{2}\right)$}

Klon PB 260 dan IRR 42 menunjukkan respon yang sama terhadap aplikasi JA, NAA dan kombinasinya. Kedua klon tersebut menunjukkan penambahan jumlah latisifer, meskipun jumlah peningkatannya berbeda antar perlakuan (Tabel 2). Penambahan latisifer oleh perlakuan zat pengatur tumbuh klon PB 260 lebih tinggi dibandingkan klon IRR 42. Kombinasi JA+NAA menghasilkan pertambahan jumlah latisifer yang paling banyak dan diikuti oleh perlakuan JA dan NAA. Secara tunggal JA lebih kuat menginduksi diferensiasi latisifer dibandingkan dengan NAA baik pada klon PB 260 maupun klon IRR 42. Secara umum klon PB 260 memiliki latisifer yang lebih padat dibanding klon IRR 42. Kombinasi JA dengan NAA berinteraksi secara sinergis terhadap klon PB 260 dan IRR 42 dalam menginduksi pertambahan jumlah latisifer pada tanaman Hevea brasiliensis. Pertambahan jumlah latisifer mengindikasikan terjadinya peningkatan aktivitas diferensiasi kambium menjadi latisifer. Peningkatan aktivitas diferensiasi ini disebabkan oleh interaksi antara jenis zat pengatur tumbuh dan klon dan perbedaan genetik pada masing-masing klon.

Tabel 2. Pengaruh pemberian JA, NAA dan kombinasinya terhadap kepadatan latisifer (per $500 \mu \mathrm{m}^{2}$ ) pada klon karet PB 260 dan IRR 42

\begin{tabular}{cccccc}
\hline Perlakuan & Kontrol & JA & NAA & JA+NAA & Rataan \\
\hline PB 260 & $16,78^{\text {de }}$ & $27,45^{\text {b }}$ & $21,11^{\text {cd }}$ & $36,11^{\text {a }}$ & 25,36 \\
IRR 42 & $13,22^{\mathrm{e}}$ & $22,11^{\text {cd }}$ & $17,78^{\text {de }}$ & $26,67^{\text {bc }}$ & 19,95 \\
\hline
\end{tabular}

Keterangan: Angka-angka yang tidak diikuti huruf pada kelompok perlakuan yang sama menunjukkan tidak berbeda nyata menurut Uji Duncan's Multiple Range Test pada taraf $\alpha$ 5\%

Berdasarkan penelitian Hao \& Wu (2000) dan Wijayati et al. (2005), JA dan auksin merupakan zat pengatur tumbuh (ZPT) yang menginduksi pertambahan jumlah sel-sel sekretori tanaman. Wu et al. (2016), melaporkan aplikasi JA dan perkursor JA (asam linolenat) menginduksi pembentukan baris-baris latisifer pada floem sekunder. Ini membuktikan bahwa laju diferensiasi latisifer dari kambium vaskuler dipengaruhi oleh JA dan prekursor JA. JA menginduksi diferensiasi latisifer primer dan sekunder pada berbagai tingkatan pertumbuhan batang dan daun pada konsentrasi 0,005\% (Hao \& Wu 2000). Kulit berkembang dengan cara yang alami tetapi kecepatannya meningkat jika diberi stimulasi etefon dan auksin (2,4-D) (Jacob et al, 1989). Auksin eksogen akan mempengaruhi dinamika kadar auksin endogen. Koryati (2016) menyebutkan bahwa aplikasi kombinasi auksin dengan sitokinin menginduksi jumlah latisifer pada semua klon yang diuji. Pemberian ZPT pada konsentrasi tertentu akan menstimulasi pertumbuhan tanaman, karena meningkatkan level hormon endogen (Wattimena, 1988). Ketebalan kulit bertambah seiring dengan pertambahan umur tanaman. Pertumbuhan tebal kulit merupakan karakteristik spesifik pada klon tertentu. Pemulia tanaman karet melakukan evaluasi ketebalan kulit adalah untuk mendapatkan tanaman yang mempunyai kulit yang cukup tebal sehingga diharapkan menghasilkan baris-baris latisifer yang lebih banyak (Gambar 1). Baris-baris latisifer yang satu dengan yang lain memiliki korelasi positif terhadap ketebalan kulit tanaman (Gomez, 1982). Menurut Woelan dan Sayurandi (2009), anatomi kulit saat tanaman belum menghasilkan juga perlu diketahui untuk memprediksi potensi produktivitasnya.

Jumlah latisifer pada jaringan kulit berumur 50 hari berkisar antara 13 sampai $36 \mathrm{sel} / 500 \mu \mathrm{m}^{2}$. Penelitian tentang diferensiasi latisifer yang telah dilakukan oleh Wei-Min et al. (2003) menunjukkan bahwa aplikasi JA menginduksi baris latisifer sekunder pada floem yang dilukai. Baris latisifer sekunder yang terbentuk sangat dekat dengan 
kambium, berjumlah lebih banyak, berukuran lebih kecil dan berisi sedikit karet yang ditandai dengan warna coklat yang terang (Sando et al., 2009). Tomogami et al. (2012) menjelaskan bahwa asam jasmonat eksogen (dalam bentuk metil jasmonat) ditransport ke dalam jaringan tanaman dan mengalami metabolisme menjadi asam jasmonat.
Jasmonat eksogen diketahui mempunyai beberapa perananan fisiologis yaitu menghambat perkecambahan biji, pertumbuhan kalus, pertumbuhan akar, fotosintesis, dan biosintesis ribulosa bifosfat karboksilase melalui berbagai proses (Davies, 1995).

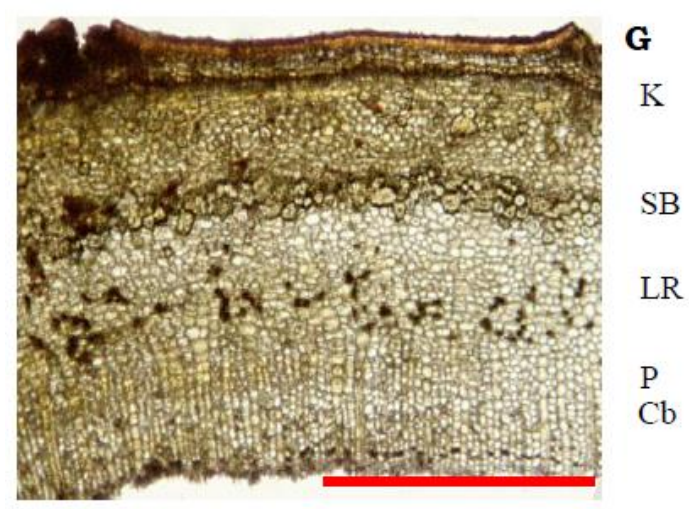

Gambar 1. Sayatan melintang kulit batang tunas lateral Hevea brasiliensis klon PB 260 dengan pewarnaan sudan 3, G: jaringan gabus; K: kambium gabus; SB: Sel batu; LR: Latisifer; P: Parenkim; Cb: Kambium, Perbesaran 4 X 10, Scale bar $500 \mu \mathrm{m}$.

\section{c. Diameter Latisifer $(\mu \mathrm{m})$}

Klon IRR 42 mempunyai diameter sel latisifer yang lebih besar jika dibandingkan dengan klon PB 260. Pemberian JA, NAA dan kombinasinya menyebabkan diameter kedua klon karet mengecil jika dibandingkan dengan kontrol. Jika dikaitkan dengan variabel sebelumnya, perlakuan kontrol memiliki jumlah latisifer yang paling sedikit tetapi memiliki diameter yang besar.
Dengan demikian induksi zat pengatur tumbuh yang diberikan mengakibatkan pertambahan jumlah latisifer dan membuat ukurannya semakin kecil. Diameter latisifer yang bertambah kecil diduga karena aktifitas pembelahan sel-sel latisifer meningkat sehingga menghambat proses perbesaran selnya. Diameter sel-sel latisifer paling kecil ditemukan pada perlakuan kombinasi JA+NAA, dan dipengaruhi oleh jenis klon.

Tabel 3. Pengaruh pemberian JA, NAA dan kombinasinya terhadap ukuran diameter latisifer $(\mu \mathrm{m})$ pada klon karet PB 260 dan IRR 42

\begin{tabular}{cccccc}
\hline Perlakuan & Kontrol & JA & NAA & JA+NAA & Rataan \\
\hline PB 260 & $36,09^{\mathrm{b}}$ & $30,79^{\mathrm{c}}$ & $30,53^{\mathrm{c}}$ & $27,07^{\mathrm{d}}$ & 31,12 \\
IRR 42 & $44,43^{\mathrm{a}}$ & $32,21^{\mathrm{c}}$ & $33,23^{\mathrm{b}}$ & $31,77^{\mathrm{c}}$ & 35,41 \\
\hline
\end{tabular}

Keterangan: Angka-angka yang tidak diikuti huruf pada kelompok perlakuan yang sama menunjukkan tidak berbeda nyata menurut Uji Duncan's Multiple Range Test pada taraf $\alpha$ 5\%

Parameter-parameter histologi merupakan komponen yang penting untuk menentukan karakter produksi pada beberapa progeni tanaman Hevea brasiliensis. Menurut Sethuraj \& Mathew (1992), salah satu parameter histologi yang juga penting adalah diameter latisifer. Besaran diameter pembuluh lateks sangat dipengaruhi oleh jenis klon dan umur tanaman (Woelan dan Sayurandi, 2009). 
Besaran diameter juga dipengaruhi oleh posisi latisifer terhadap kambium pada jaringan kulit (Sando et al. 2009). Ukuran latisifer di dekat kambium lebih kecil dibandingkan latisifer yang terletak lebih dekat dengan epidermis.

\section{Analisis Fisiologi}

\section{a. Kadar Sukrosa Lateks (mM)}

Perhitungan dan sidik ragam kadar sukrosa menunjukkan perbedaan klon dan interaksi antara klon dengan jenis zat pengatur tumbuh berbeda nyata pada tunas muda berumur 2 bulan (Tabel 4). Kadar sukrosa pada klon PB 260 lebih rendah dibandingkan kadar sukrosa klon IRR 42 dan tidak dipengaruhi oleh perlakuan JA, NAA dan kombinasinya. Sedangkan kadar sukrosa klon IRR
42 dipengaruhi oleh aplikasi IAA dan NAA jika dibandingkan oleh kontrol. Kadar sukrosa yang dihasilkan berkisar antara 21-38 $\mathrm{mM}$ tergolong ke dalam kategori tinggi (Jacob et al., 1989). Perbedaan kadar sukrosa lateks ini mungkin disebabkan karena perbedaan genetik yang mendasar antara klon PB 260 dan klon IR 42. Tingginya kadar sukrosa lateks ini kemungkinan disebabkan karena belum aktifnya metabolisme lateks di dalam latisifer, di mana proses perombakan sukrosa menjadi karet belum intensif. Pada klon IRR 42, kadar sukrosa menurun dengan adanya perlakuan ZPT dibandingkan dengan kontrol. Hal ini kemungkinan dipengaruhi oleh pembagian sukrosa yang lebih besar untuk pembentukan jaringan kulit dan batang pada klon IRR 42.

Tabel 4. Pengaruh pemberian JA, NAA dan kombinasinya terhadap kadar sukrosa (mM) lateks pada klon karet PB 260 dan IRR 42.

\begin{tabular}{cccccc}
\hline Perlakuan & Kontrol & JA & NAA & JA+NAA & Rataan \\
\hline PB 260 & 33,84 & 37,75 & 37,26 & 34,77 & $35,91^{\mathrm{A}}$ \\
IRR 42 & $38,34^{\mathrm{a}}$ & $21,43^{\mathrm{c}}$ & $27,13^{\mathrm{b}}$ & $25,74^{\mathrm{b}}$ & $28,16^{\mathrm{B}}$ \\
\hline
\end{tabular}

Keterangan: Angka-angka yang tidak diikuti huruf pada kelompok perlakuan yang sama menunjukkan tidak berbeda nyata menurut Uji Duncan's Multiple Range Test pada taraf $\alpha 5 \%$

Kisaran kadar sukrosa pada saat tanaman dewasa mulai disadap adalah $3,75-6,91 \mathrm{mM}$ (Koryati 2016). Dinamika kadar sukrosa pada lateks sangat dipengaruhi oleh tingkat metabolisme dalam jaringan (Jacob et al., 1989). Pada tanaman dewasa, kadar sukrosa yang rendah mengindikasikan bahwa metabolisme bahan asimilat sangat intensif, sehingga cadangan karbohidrat terkuras untuk produksi karet. Sebaliknya, kadar yang tinggi menunjukkan kurang aktifnya metabolisme tanaman. Kadar sukrosa yang tinggi bisa juga berarti bahwa sel latisifer sudah tidak berfungsi lagi atau mengalami degenerasi (Kuswanhadi et al., 2009; Sumarmadji et al., 2006).

Alokasi sukrosa ke latisifer didasari pada keseimbangan antara sukrosa yang dihasilkan dan dimanfaatkan (Jacob et al., 1989). Kehadiran gula pada latisifer merupakan komponen utama pengatur metabolisme lateks, yang bergantung pada ketersediaan karbohidrat pada jaringan latisifer dan kegunaannya dalam tingkatan sel. Katabolisme sukrosa menghasilkan molekul asetat sebagai senyawa prekusor rantai isoprene dan sebagian menghasilkan energi untuk metabolisme lateks. Konsentrasi gula yang tinggi di dalam lateks memiliki korelasi yang positif terhadap produksi lateks (Priyadarshan, 2011).

\section{b. Kadar Fosfat Anorganik Lateks}

Kandungan fosfat anorganik lateks berkisar antara 2-8 mM yang tergolong dalam kategori rendah-sedang menurut Jacob et al. (1989). Kisaran ini yang menunjukkan aktivitas metabolisme lateks belum intensif di dalam latisifer tunas-tunas muda. Pada klon PB 260, perlakuan zat pengatur tumbuh tidak mempengaruhi kadar fosfat anorganik, sedangkan kadar fosfat anorganik lateks klon IRR 42 cenderung mengalami penurunan pada perlakuan JA. Penurunan kadar fosfat anorganik ini 
kemungkinan berkaitan biosintesis lateks yang rendah dan aktivitas diferensiasi pada latisifer yang tinggi. Pada umur cabang 2 bulan diduga latisifer belum melakukan aktifitas metabolik yang intensif dalam merubah sukrosa menjadi partikel karet.
Korelasinya dengan variabel jumlah dan diameter latisifer adalah sebagian fosfat anorganik digunakan pada aktifitas pembelahan sel-sel kulit dan diferensiasi latisifer.

Tabel 5. Pengaruh pemberian JA, NAA dan kombinasinya terhadap kadar fosfat anorganik (mM) lateks pada klon karet PB 260 dan IRR 42

\begin{tabular}{cccccc}
\hline Perlakuan & Kontrol & JA & NAA & JA+NAA & Rataan \\
\hline PB 260 & 8,46 & 7,16 & 7,88 & 8,34 & 7,96 \\
IRR 42 & $8,24^{\mathrm{a}}$ & $2,26^{\mathrm{b}}$ & $6,14^{\mathrm{a}}$ & $6,42^{\mathrm{a}}$ & 5,77 \\
\hline
\end{tabular}

Keterangan: Angka-angka yang tidak diikuti huruf pada kelompok perlakuan yang sama menunjukkan tidak berbeda nyata menurut Uji Duncan's Multiple Range Test pada taraf $\alpha 5 \%$

Menurut Kuswanhadi et al., (2009), kadar fosfat anorganik lateks yang tinggi menunjukkan aktifitas metabolisme lateks yang aktif atau justru sebaliknya. Peningkatan aktivitas metabolisme lateks dipengaruhi oleh beberapa hal seperti iklim, pelukaan, dan stimulasi. Karakter fisiologi lateks seperti kadar sukrosa, fosfat anorganik, magnesium, tiol, $\mathrm{pH}$ dan potensial redoks merupakan faktor yang penting dalam biosintesis karet. Stimulasi pada tanaman karet dapat mempengaruhi perubahan karakter fisiologi lateks tersebut (Sethuraj \& Mathew, 1992; Sumarmadji, 2000; Silpi et al., 2006).

Korelasi antara variabel fosfat anorganik dan sukrosa dapat digunakan untuk menetapkan tipe metabolisme dari tanaman (Silpi et al., 2006). Kehadiran fosfat anorganik menunjukkan metabolisme energi lateks. Demikian hal dengan sukrosa, selain sumber energi juga merupakan bahan baku untuk menyusun isoprene atau partikel karet. Fosfat mempengaruhi sintesis nukleotida, transfer energi dan sintesis isopren melalui ikatan adenosin fosfat dan pirofosfat (Sethuraj \& Mathew, 1992; Sumarmadji, 2000).

Pada tanaman dewasa yang belum aktif penyadapannya kandungan fosfat anorganik tergolong rendah yaitu 3,24 - 4,8 mM (Koryati 2016). Kisaran optimal kadar fosfat anorganik lateks pada tanaman yang telah disadap adalah 10$20 \mathrm{mM}$ (Jacob et al., 1989). Tanaman dengan kadar fosfat yang tinggi mendukung berlangsungnya proses metabolisme yang aktif dalam sitosol sel latisifer terutama biosintesis lateks (Kurnia, 2011; Sumarmadji, 2000). Semakin rendah kadar fosfat anorganik dari kisaran optimal tersebut berarti kemampuan tanaman dalam melakukan metabolisme juga semakin berkurang. Sebaliknya, jika tinggi kadar fosfat anorganik melebihi dari kisaran optimalnya, mengindikasikan bahwa tanaman mengalami telah mengalami cekaman atau mengindikasikan tanaman terserang penyakit (Jacob et al., 1989). Fosfat anorganik memiliki muatan negatif yang membantu menstabilkan partikel karet sehingga memperlambat koagulasi lateks dan memperlama waktu aliran lateks.

\section{c. Produksi Karet (mg/tunas/sadap)}

Analisis produksi karet dilakukan dengan cara menampung tetesan lateks hingga aliran lateks berhenti pada kertas saring yang sudah diketahui beratnya dan melakukan pemanasan lateks di dalam oven hingga diperoleh berat karet kering. Perhitungan dan sidik ragam menunjukkan produksi karet antara kedua klon berbeda nyata, sedangkan interaksi antara klon dengan jenis zat pengatur tumbuh tidak menunjukkan berbeda nyata terhadap produksi karet pada tunas umur 2 bulan (Tabel 6).

Klon PB 260 memiliki produksi karet yang lebih tinggi dibandingkan klon IRR 42. Hal ini disebabkan karena perbedaan tingkat metabolisme pada masing-masing klon dalam merubah sukrosa menjadi partikel karet dengan suplai energi yang berasal dari fosfat. Klon PB 260 dikategorikan 
kelompok metabolisme tinggi, sedangkan IRR 42 tergolong metabolisme rendah (Sumarmadji et al., 2006). Selain itu, variabel jumlah latisifer memberikan kontribusi paling tinggi terhadap produksi karet yang dihasilkan oleh klon PB 260 dan IRR 42, dalam hal ini jumlah latisifer klon PB 260 lebih banyak dibandingkan klon IRR 42.

Tabel 6. Pengaruh pemberian JA, NAA dan kombinasinya terhadap produksi karet (mg/tunas/sadap) pada klon karet PB 260 dan IRR 42

\begin{tabular}{cccccc}
\hline Perlakuan & Kontrol & JA & NAA & JA+NAA & Rataan \\
\hline PB 260 & 60,81 & 56,73 & 61,05 & 62,64 & $60,31^{\mathrm{a}}$ \\
IRR 42 & 44,36 & 43,22 & 41,09 & 42,81 & $42,87^{\mathrm{b}}$ \\
\hline
\end{tabular}

Keterangan: Angka-angka yang tidak diikuti huruf pada kelompok perlakuan yang sama menunjukkan tidak berbeda nyata menurut Uji Duncan's Multiple Range Test pada taraf $\alpha$ 5\%

Menurut Jacob et al. (1989), regenerasi lateks dikontrol oleh empat mekanisme yakni ketersediaan sukrosa, regulasi aktivitas enzimatik, ketersediaan energi biokimia dan regenerasi in situ dan reaksi yang menginduksi fenomena penuaan dan reaksi antioksidan yang melawan molekul oksigen toksik atau detoksifikasi latisifer. Hasil karet kering (gram/pohon/sadap) suatu klon karet bergantung pada tebal kulit dan ukuran lilit batang. Pada klon yang sama produksi akan lebih besar pada tanaman dengan tebal kulit dan lilit batang yang besar (Oktavia \& Lasminingsih, 2010). Jika dibandingkan antar klon, kedua variabel ini tidak memiliki hubungan yang positif terhadap produksi karet. Klon IRR 42 yang memiliki kulit yang lebih tebal memiliki produksi karet yang lebih rendah dibandingkan dengan klon PB 260 yang memiliki kulit lebih tipis.

Lateks umumnya mengandung $25-40 \%$ bahan padat yang mengandung senyawa kimia kompleks antara lain karet hidrokarbon, protein, lipid, karbohidrat, garam anorganik dan lain lain. Kandungannya bergantung pada jenis tanaman dan penyadapan. Pada tanaman yang belum disadap kandungan karet pada tanaman mampu mencapai 60\% atau lebih (Sethuraj \& Mathew, 1992).

Parameter histologi dan fisiologi pada tingkat tunas muda dapat secara akurat membedakan antara dua klon yang berbeda sifat metabolismenya. Sifatsifat genetik yang berkaitan dengan produktivitas tanaman karet dapat diketahui dengan menganalisis kedua parameter tersebut sejak tanaman muda. Dengan demikian pengamatan kedua parameter tersebut dapat mempersingkat siklus seleksi pemuliaan klon karet hingga 5 tahun lebih cepat dibandingkan seleksi konvensional.

\section{KESIMPULAN}

Asam jasmonat, NAA dan kombinasi asam jasmonat dengan NAA meningkatkan jumlah latisifer. Kombinasi JA dan NAA paling efektif menginduksi diferensiasi latisifer dan respon terhadap zat pengantur tumbuh tersebut berbeda antar klon yang diuji. Diferensiasi latisifer klon PB 260 lebih tinggi dibandingkan klon IRR 42 dan berkorelasi dtinggi dengan hasil karet. Perlakuan kedua zat pengatur tersebut berpengaruh negatif terhadap tebal kulit, diameter latisifer, serta mempengaruhi aktivitas metabolisme lateks pada klon IRR 42. Kadar sukrosa, fosfat anorganik dan produksi karet klon IRR 42 lebih rendah dibandingkan klon PB 260 yang menggambarkan aktivitas metabolisme kedua klon berbeda. Analisis histologi kulit dan fisiologi lateks pada tunas muda tanaman karet dapat digunakan sebagai pendeteksi potensi produktivitas dan sifatmetabolisme tanaman karet.

\section{UCAPAN TERIMA KASIH}

Ucapan terima kasih kepada Balai Penelitian Sungei Putih, Pusat Penelitian Karet yang telah memberikan bantuan fasilitas penelitian berupa bahan tanam di kebun percobaan dan berbagai peralatan laboratorium. 


\section{DAFTAR PUSTAKA}

Breton F., M. Coupe, C. Sanier, J. d'Auzac. 1997. Demonstration $\beta-1,3$-glucanase activities in lutoid of Hevea brasiliensis latex. J. Nat. Rubb. Res, 10 (1): 37-45.

Jacob, J.1., J.C. Prevot, D. Roussel, R. Lacrotte, E. Serres, J. d'Auzac, J.-M. Eschbach, and H. Omont L. 1989. Physiology of Rubber Tree Latex. In, J. Auzac, J.L. Jacob, H. Chresti (eds). Physiology of Rubber Tree Latex. CRC Press, Inc Boca Raton. 348-381.

Daruliza, K.M, K.L. Lam, K.L. Yang, J.T. Priscilla, E. Sunderasan, M.T. Ong. 2011. Antifungal effect of Hevea brasiliensis latex C-serum on Aspergillus niger. Eur Rev Med Pharmacol Sci. 15(9): 1027-1033.

Daslin, A., Sayurandi, S.A. Pasaribu, 2010. Potensi keunggulan klon karet harapan IRR seri 200 dari hasil seleksi pohon induk. Jurnal Penelitian Karet. 28(1): 5 - 12.

Daslin, A., S. Woelan, I. Suhendry. 2009. Bahan Tanaman Klon Karet Unggul. Sungei Putih: Pusat Penelitian Karet. 34 hal.

Davies, P, J. 1995. Plant Hormones: Phisiology, biochemistry and molecular biology. Second Edition. Netherlands: Kluwer Academic Publishers. 179 pages.

Dische Z.M. 1962. Carbohydrate Chemistry. Acad. Press. New York. 125 pages.

Gomez, J. B., 1982. Anatomy of Hevea and Its Influence on Latex Production. Monografi. Kuala Lumpur: Malaysian Rubber Research and Development Board. 30 pages.

Hao, B. Z., J.L. Wu. 2000. Laticifer Differentiation in Hevea brasiliensis: Induction by Exogenous Jasmonic Acid and Linolenic Acid. Annals of Botany. 85: 37-43.

Koryati, T. 2004. Pemanfaatan Zat Pengatur Tumbuh Untuk Memperpendek Masa Non Produktif Pada Tanaman Karet (Hevea brasiliensis). Jurnal Penelitian Bidang Ilmu Pertanian. 2(2): 24-31.

Koryati, T. 2016. Upaya mempercepat matang sadap dan karakter produksi lateks beberapa klon karet melalui penggunaan zatpengatur tumbuh. Disertasi. Sekolah Pascasarjana Universitas Sumatra Utara

Kurnia, F. 2011. Studi Karakter Fisiologis Dan Sifat Aliran Lateks Klon Karet (Hevea brasiliensis Muell Arg.) IRR Seri 300. Skripsi. Medan: Universitas Sumatera Utara.

Kuswanhadi, Sumarmadji, Karyudi, T. H. S Siregar. 2009. Optimasi Produksi Klon Karet Melalui Sistem Eksploitasi Berdasarkan Metabolisme Lateks. Prosiding Lokakarya Nasional Pemuliaan Tanaman: 152. Pusat Penelitian Karet.

Oktavia, F., M. Lasminingsih. 2010. Pengaruh kondisi daun tanaman karet terhadap keragaman hasil sadap beberapa klon seri IRR. Jurnal Penelitian Karet. 28(2): 39.

Priyadarshan, P, M. 2011. Biology of Hevea Rubber. United Kingdom: MPG Books Group. 54, 58.

Rachmawan, A dan Sumarmadji. 2007. Kajian karakter fisiologi dan sifat karet pada klon PB260 menjelang buka sadap. Jurnal Penelitian Karet. 25(2): 62-65.

Sando, T., Hayashi, T., Takeda, T., Akiyama, Y., Nakazawa, Y., Fukusaki, E. and Kobayashi, A. 2009. Histochemical Study of Detailed Laticifer Structure and Rubber Biosynthesis Related Protein Localization in Hevea brasiliensis Using Spectral Confocal Laser Scanning Microscopy. Planta. 230: 215-225. DOI 10.1007/s00425-009-0936-0

Sethuraj, M. R., N.M. Mathew. 1992. Natural Rubber: biology, Cultivation and Technology. Netherlands: Elsevier Science Publisher B. V. 145-147.

Silpi, U., Chantuma, P., Kasemsap, P., Thaler, P., Thanisawanyangkura, S., Lacointe, A., Ameglio, T., Gohet, E. 2006. Sucrose And Metabolism Distribution Patterns In The Laticiferes Of Three Hevea brasiliensis Clones: Effect Of Tapping And Stimulation On The Tree Trunk. Journal Of Rubber Research. 9(2): 117.

Sumarmadji, Karyudi, Siregar, T. H. S., Junaidi, U. 2006. Optimasi produktivitas klon karet 
melalui berbagai sistem eksploitasi. Prosiding Lokakarya Nasional Pemuliaan Tanaman: 125. Pusat Penelitian Karet.

Taussky, H. H., E. Shorr. 1953. A Micro Colorimetric Methods For the Determination Of Inorganic Phosphorus. Journal Of Biology Chemistry. 202: 675-685.

Tomogami, S., K. Noge, M. Abe, G. Agrawal, R. Rakwal. 2012. Methyl Jamonate Is Transported To Distal Leaves Via Vascular Process Metabolizing Itself Into Ja-Ile And Triggering VOCs Emission As Defensive Metabolites. Plant Signaling \& Behavior. 7: 11. 1-4.

Wattimena, G. A. 1988. Zat Pengatur Tumbuh Tanaman. Bogor: Institut Pertanian Bogor.

Wei-Min, T., S. Min-Jing, Y. Feng-Yi, W. Ji-Lin, H. Bing-Zhong, C. Ke-Ming. 2003. Localized Effects of Mechanical Wounding ang Exogenous Jasmonic Acid on The Induction of Seceondary Laticifer Differentiation in Relation to The Distribution of Jasmonic Acid in Hevea brasiliensis. Acta Botanica Sinica. 45(11): 1366-1372.

Wijayati, A., Solichatun, Sugiyarto. 2005. Pengaruh Asam Indol Asetat Terhadap Pertumbuhan, Jumlah dan Diameter Sel Sekretori Rimpang Tanaman kunyit (Curcuma domestica Val.). Jurnal Biofarmasi. 3(1): 19-20.

Woelan, S dan Sayurandi. 2009. Keragaan Klon Karet Unggul Harapan IRR Seri 400 Selama Tanaman Belum menghasilkan Di Pengujian Plot Promosi. Prosiding Lokakarya Nasional Pemuliaan Tanaman Karet: 236-244. Pusat Penelitian Karet.

Wu S., S. Zhang, J. Chao, X. Deng, Y. Chen, M. Shi, W.M. Tian. 2016. Transcriptome analysis of the signalling networks in coronatine induced secondary laticifer differentiation from vascular cambia in rubber trees. Scientific Reports: 1 - 13. DOI: 10.1038/srep36384 